\title{
Sex-limited protein: in vitro and in vivo functions
}

\author{
F. J. M. BEURSKENS, J. D. M. KUENEN, F. HOFHUIS*, A. C. FLUIT, D. M. ROBINS† \& H. VAN DIJK \\ Eijkman-Winkler Institute for Microbiology, Infectious Diseases, and Inflammation and *Department of Immunology, Utrecht \\ University Hospital, Utrecht, The Netherlands, and †Department of Human Genetics, The University of Michigan, Ann Arbor, MI, USA
}

(Accepted for publication 2 February 1999)

\begin{abstract}
SUMMARY
Mouse complement component $\mathrm{C} 4$ exists in two isoforms, $\mathrm{C} 4$ and a protein with expression restricted to male animals called sex-limited protein (Slp). Although Slp is about 95\% homologous to C4, it is generally believed to be non-functional, at least in conventional haemolytic complement assays. In a previous study, however, we showed that Slp is haemolytically active in a C1-inhibitor (C1INH)regulated, EDTA-resistant mouse complement activation pathway. To study other possible implications of this finding, we generated constitutively expressing Slp-transgenic mice. The transgene was crossed into otherwise Slp-deficient C57B1/6J and NZB mice. Members of the third backcross generation of $\mathrm{C} 57 \mathrm{~B} 1 / 6 \mathrm{~J}$ mice were tested for functional Slp and classical and alternative complement pathway activities $\left(\mathrm{CH}_{50}\right.$ and $\mathrm{AP}_{50}$ levels, respectively). Slp-transgenic $\mathrm{C} 57 \mathrm{~B} 1 / 6 \mathrm{~J}$ mice showed enhanced $\mathrm{CH}_{50}$, but normal $\mathrm{AP}_{50}$ levels when compared with non-transgenic littermates. To discover a possible protective role for Slp in spontaneous systemic lupus erythematosus (SLE) in NZB $\times N Z W(N Z B \times W)$ mice, the third backcross generation of Slp-transgenic NZB mice was mated with NZW mice and the development of SLE in the female offspring was followed. In these introductory experiments, Slptransgenic NZB $\times W$ animals presented with a significantly extended life span. Our results imply that Slp is a mouse complement component with functions which partially resemble some of those of human C4A.
\end{abstract}

Keywords complement lupus mouse Slp transgenic

\section{INTRODUCTION}

The class III region of the MHC of the mouse, also known as the $\mathrm{S}$ region, encodes serum proteins including $\mathrm{C} 2$, factor $\mathrm{B}, \mathrm{C} 4(\mathrm{Ss})$, and sex-limited protein (Slp) [1-4]. Although Slp has long been considered non-functional, data from our group suggest that it is involved in an EDTA-resistant complement activation pathway, which is - at least partially_different from both classical and alternative activation pathways [5]. The Slp gene is considered to be a duplication of the mouse $\mathrm{C} 4$ gene with about $95 \%$ homology to $\mathrm{C} 4$ at both the DNA and protein levels [6]. However, the protein is incapable of rendering C4-deficient guinea pig serum haemolytic [7]. Furthermore, Slp is resistant to cleavage by activated human and mouse $\mathrm{C} 1 \mathrm{~s}$ and the mouse $\mathrm{C} 1 \mathrm{~s}$-like protease Ra-reactive factor, whereas mouse $\mathrm{C} 4$ is not [8-10]. These are probably the main reasons why Slp has been considered non-functional. These

Correspondence to: Dr F. J. M. Beurskens, Eijkman-Winkler Institute for Microbiology, Infectious Diseases, and Inflammation, Utrecht University Hospital, HP G04.614, Heidelberglaan 100, NL-3584 CX, Utrecht, The Netherlands.

E-mail: F.J.M.Beurskens@1ab.azu.nl findings seem to rule out that $\mathrm{C} 1$ or the Ra-reactive factor play an important role in Slp-mediated complement activation. The following questions then remain: at what level in the complement cascade does Slp act and what are the in vivo implications?

As already stated, the Slp gene is a member of the MHC class III family, a family that includes not only other complement components, but also complement-unrelated proteins [11]. Therefore, a role for Slp-linked genes in Slp-mediated complement activation cannot be entirely ruled out. In order to assign definitely functional activity to Slp and generate mouse models for functional Slp activity, an Slp-expressing allele was introduced into mice lacking a functional Slp gene product. The insert of a cosmid clone encompassing a full-length Slp gene was used for the microinjection of oocytes. The gene chosen originated from the B10.WR7 mouse strain, which expresses Slp without the characteristic dependence on androgen [12]. The origin of this gene is probably the presence of additional Slp genes in the strain that have undergone recombination with a neighbouring $\mathrm{C} 4$ gene (and subsequent multiplication). This did result in hybrid genes that have C4regulatory sequences preceding Slp-coding regions and thus constitutive (C4-like) expression rather than limitation to mature 
males $[2,13,14]$. The insert of cosmid clone 38.3 was used because the intact Slp gene contained within this clone accounts for the majority of Slp in B10.WR7 mice [2,13].

The objective of the present study was to obtain more insight into Slp function(s) by comparing the activities of sera from Slptransgenic and Slp-deficient littermates in different assays of mouse complement activation, including the Slp-dependent EDTA-resistant pathway [5]. In an introductory experiment with systemic lupus erythematosus (SLE)-prone, Slp-transgenic $\mathrm{NZB} \times \mathrm{W}$ mice, we aimed at studying the role of Slp in murine lupus erythematosus.

\section{MATERIALS AND METHODS}

Animals

Transgenic mice were generated by the Transgenic Animal Model Core of the University of Michigan's Biomedical Research Core facilities. The purified DNA fragment was microinjected into fertilized eggs from $\mathrm{F}_{1}$ hybrid zygotes from $\mathrm{C} 57 \mathrm{Bl} / 6 \mathrm{~J}$ and $\mathrm{C} 57 \mathrm{Bl} /$ $6 \mathrm{~J} \times \mathrm{SJL} / \mathrm{J}$ parents. The eggs were then transferred to pseudopregnant CD-1 mice, as described by Hogan et al. [1]. C57Bl/ $6 \mathrm{~J} \times \mathrm{SJL} / \mathrm{J}$ mice were obtained from Jackson Laboratory (Bar Harbor, ME) and CD-1 mice from Charles River (Wilmington, MA). Transgenic founders, identified by Southern blotting of tail DNAs, were mated to $\mathrm{C} 3 \mathrm{H}$ mice (Jackson) and transgenic progeny to $\mathrm{C} 57 \mathrm{Bl} / 6 \mathrm{~J}$ and subsequently also to NZB mice (Fig. 1). Slptransgenic mice from these established, independent lines (A, B and $\mathrm{C}$ ) were then selected on the basis of functional Slp in serum. After the first backcross procedure in $\mathrm{C} 57 \mathrm{~B} 1 / 6 \mathrm{~J}$ mice, offspring were tested for the presence of transgene and the absence of SJL/J Slp gene using Southern blotting. Incidentally, genotypes were confirmed by reverse transcriptase-polymerase chain reaction (RTPCR). All mouse procedures were approved by the University of Michigan Committee on the Use and Care of Animals and were conducted in accordance with the principles and procedures outlined in the NIH Guidelines for the Care and Use of Experimental Animals.

The second Slp-transgenic C57Bl/6J generation was mated to NZB/Ola//Hsd mice (Harlan Olac Ltd, Bicester, UK) and, after three backcrosses with NZB, to NZW mice in order to obtain female SLE-prone NZB $\times W$ mice (NZW/Ola/Hsd; Fig. 1). The mice used in these experiments and haemolytic complement tests were matched for sex and age (by making comparisons within the same litters). In the Netherlands, all mice were bred and maintained at the Central Animal Facilities of Utrecht University.

\section{DNAs}

An androgen-independent Slp gene was obtained from cosmid 38.3, which contains the full-length 17-kb SlpB gene from the B10.WR7 strain [2]. The 26-kb EcoRI fragment encompassing the complete gene and including approx. $5 \mathrm{~kb}$ of $5^{\prime}$ flanking sequences was purified from agarose following electrophoresis to remove vector DNA and then microinjected into oocytes. Genomic DNAs used in Southern blotting were prepared either from tail biopsies of 2-week-old animals using a salting-out procedure [3] or from livers of adult mice using standard procedures. The probe used in Southern blotting was the nick-translated insert of a plasmid containing a full-length $(5.4 \mathrm{~kb}) \mathrm{C} 4 \mathrm{~d}$ cDNA constructed from overlapping $\lambda$ GT10 phage clones [4]; both Slp and C4 sequences hybridized due to their $97 \%$ sequence identity.

\section{Southern blotting}

To distinguish unequivocally between the integrated SlpB transgene and endogenous $\mathrm{C} 4$ and Slp genes, Southern blots were performed to detect the SlpB-specific 19-kb HindIII fragment [6]. Hybridization intensities also allowed the estimation of gene-copy numbers more readily than simple PCR analysis. Genomic DNA $(15 \mu \mathrm{g})$ was digested overnight with at least $5 \mathrm{U} / \mathrm{mg}$ HindIII

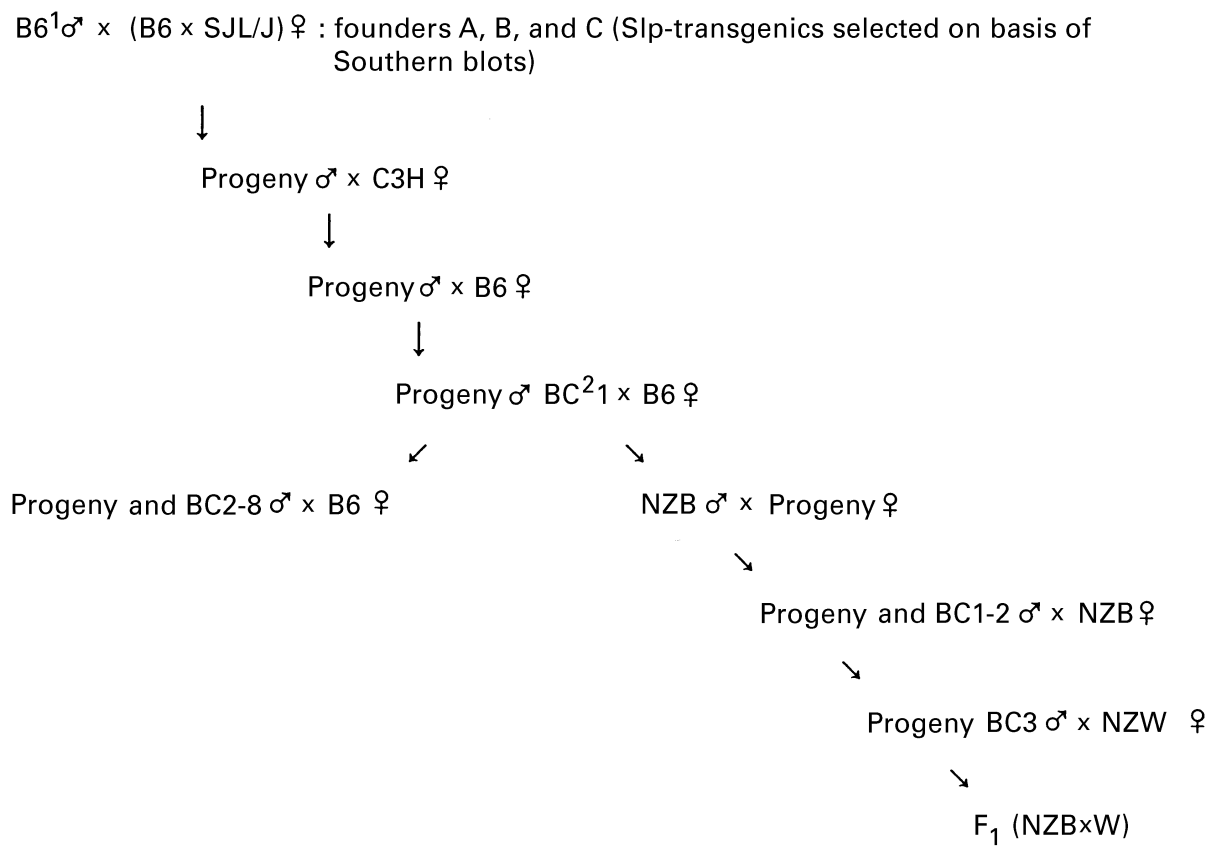

Fig. 1. Flow scheme of sex-limited protein (Slp)-transgenic C57B1/6J and NZB $\times W$ breeding. ${ }^{1} \mathrm{C} 57 \mathrm{~B} 1 / 6 \mathrm{~J}$ mice; ${ }^{2}$ backcross generation numbers. 
(Boehringer Mannheim, Mannheim, Germany) and electrophoresed on $0.4 \%$ agarose gels. The gels were then DNA-transferred to ZetaProbe GT membranes according to the manufacturer's instructions (BioRad Labs, Hercules, CA). Hybridization of the nick-translated probe and washing conditions were standard.

\section{Sera}

Male $\mathrm{C} 3 \mathrm{H} / \mathrm{FeJ}\left(\mathrm{H}-2^{\mathrm{k}}\right.$; Slp-negative) mice originally obtained from Jackson Laboratory and male $\mathrm{F}_{1}(\mathrm{BALB} / \mathrm{c} \times$ Swiss inbred; Slppositive) mice, bred and maintained at the Central Animal Facilities at Utrecht University, were used at an age of 10-15 weeks as donors of Slp reagent and Slp-containing reference serum, respectively. Mice were anaesthetized with ether and bled by retro-orbital puncture; after pooled blood was clotted for $1.5 \mathrm{~h}$ at $20^{\circ} \mathrm{C}$, serum was separated by centrifugation and stored at $-70^{\circ} \mathrm{C}$ until use.

\section{Rabbit erythrocytes}

Rabbit blood diluted 1:2 with Alsever's old solution (114 mM citrate/27 mm glucose/72 mM $\mathrm{NaCl} \mathrm{pH} 6 \cdot 1$; bioTrading, Wilnis, The Netherlands) was used as the source of rabbit erythrocytes ( $\mathrm{RaE}$ ). Before use, $\mathrm{RaE}$ were washed three times with isotonic $\mathrm{NaI}$ to elute adsorbed serum proteins and then resuspended in the appropriate buffer.

\section{Buffers}

Buffers included veronal (25 mM)-buffered saline $(750 \mathrm{~mm}$, $\mathrm{pH} 7 \cdot 35 \pm 0 \cdot 05$; VBS $\times 5$ ) which served as a five-times concentrated stock solution for the preparation of $\mathrm{VBS}^{2+}$ (containing $0.15 \mathrm{mM} \mathrm{CaCl}_{2}$ and $0.5 \mathrm{mM} \mathrm{MgCl}_{2}$; buffer for classical complement pathway activation), EGTA-VB (containing $2.5 \mathrm{~mm} \mathrm{MgCl}_{2}$ and 8 mM EGTA; buffer for alternative complement pathway activation), and EDTA-VB (containing 10 mm EDTA; buffer for haemolytic Slp assay).

\section{Haemolytic assays}

Functional Slp activity was estimated using the microtitre assay described by Van den Berg et al. [5]. Briefly, C3H/FeJ serum and Slp-containing test samples were diluted 1:10 in EDTA-VB and precipitated with $11 \%(\mathrm{w} / \mathrm{v})$ polyethylene glycol 6000 (PEG; Fluka, Buchs, Switzerland) followed by centrifugation (4000 $g$, $4^{\circ} \mathrm{C}, 1 \mathrm{~h}$ ). The precipitates were dissolved to their original volumes in EDTA-VB and subsequently incubated at $41^{\circ} \mathrm{C}$ for $45 \mathrm{~min}$. Precipitated $\mathrm{C} 3 \mathrm{H} / \mathrm{FeJ}$ serum (diluted $1: 2.5$ ) was used as reagent for Slp. After $50 \mu \mathrm{l}$ of serially diluted Slp samples were mixed with equal volumes of $11 \%$ PEG precipitates of $\mathrm{C} 3 \mathrm{H} / \mathrm{FeJ}$ serum, $50-\mu \mathrm{l}$ volumes of a $2 \% \mathrm{RaE}$ suspension in EDTA-VB were added to each well. Absorbance values $(405 \mathrm{~nm})$ of the supernates were determined after incubation at $39^{\circ} \mathrm{C}$ for $1 \mathrm{~h}$. Activities of Slp-containing sera were expressed in units (corresponding to the amount of Slp giving rise to $50 \%$ haemolysis of $\mathrm{RaE}$ in the presence of $11 \%$ PEG precipitate) per $\mathrm{ml}$.

Classical and alternative complement pathway activities $\left(\mathrm{CH}_{50}\right.$ and $\mathrm{AP}_{50}$ levels, respectively) were determined by our colourimetric microtitre assays [15]. In addition, $\mathrm{AP}_{50}$ values were determined in the presence of $5 \mathrm{mg} / \mathrm{ml}$ final concentration of Zymosan A (Sigma, St Louis, MO) [16].

\section{Statistical analysis}

Statistical significance of the results obtained for the different groups in haemolytic assays were determined using Student's $t$-test and correlations were analysed with Pearson's correlation test. The
Kaplan-Meier method was used to evaluate the survival of mice. The log rank test was used to test differences between groups of mice.

\section{RESULTS}

Generation of mice expressing Slp unlinked to other MHC class III components

Data from our group confirm that Slp, rather than being a nonfunctional pseudogene of $\mathrm{C} 4$, plays an essential role in an EDTAresistant complement activation pathway in mice [5]. Since Slp is closely linked to the mouse H-2 locus [11], the role of other MHC class III genes in this pathway cannot be entirely ruled out. To assign activity definitively to Slp and to generate mouse models for the functional assay of this activity, we introduced an Slpexpressing allele into mice otherwise 'deficient' in the EDTAresistant complement activation pathway. The insert of a cosmid clone encompassing a full-length Slp gene was used for microinjection into oocytes. The gene chosen originated from the B10.WR7 strain, which expresses Slp without the characteristic dependence on androgen [12]. This constitutive expression must have resulted from a recombination event between the Slp gene and neighbouring $\mathrm{C} 4$ genes and subsequent multiplication $[2,13,14]$. The insert of cosmid clone 38.3 was used because the intact Slp gene contained within this clone accounts for most of the Slp expression in B10.WR7 mice [2,13].

The cosmid insert was purified of vector DNA by excising a

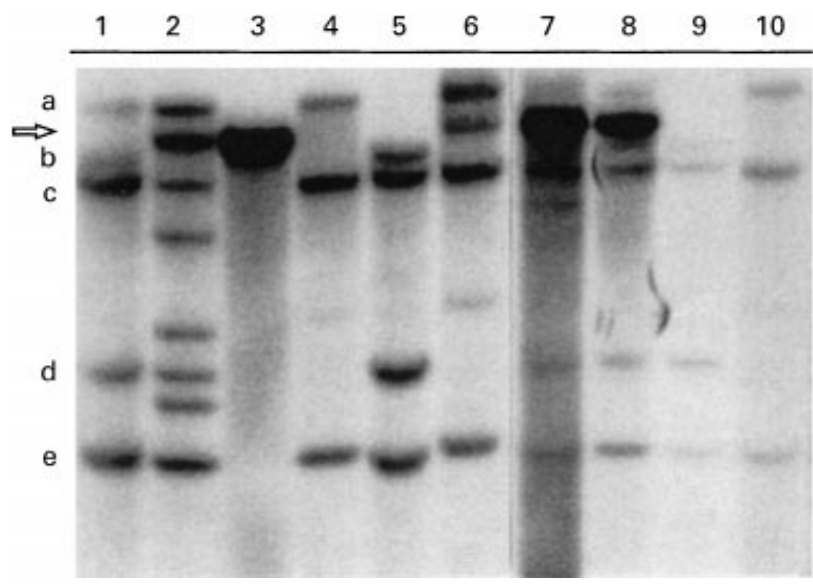

Fig. 2. Identification of transgenic mice by hybridization to a sex-limited protein (Slp)B-specific 19-kb HindIII fragment. Southern blotting was used to identify transgenic founder mice (and subsequently their transgenic offspring) and as to estimate insertion copy numbers and MHC background. Representative blots of genomic DNAs digested with HindIII (see Materials and Methods) indicate the polymorphic (haplotype-dependent) C4 and Slp fragment sizes. The lanes contain the following DNAs: lane 1, $\mathrm{F}_{1}(\mathrm{C} 57 \mathrm{~B} 1 / 6 \mathrm{~J} \times \mathrm{SJL} / \mathrm{J})$; lane 2, B10.WR7; lane 3, SlpB, $5 \mathrm{ng}$ cosmid 38.3 DNA plus $15 \mathrm{mg}$ salmon DNA; lane $4, \mathrm{SJL} / \mathrm{J}$; lane $5, \mathrm{C} 57 \mathrm{Bl} / 6 \mathrm{~J}$; lanes 6-8, progeny $\mathrm{C} 57 \mathrm{~B} 1 / 6 \mathrm{~J} \times(\mathrm{C} 57 \mathrm{~B} 1 / 6 \mathrm{~J} \times \mathrm{SJL} / \mathrm{J})$ positive for the transgene (founders for lines A, B, and C, respectively); lanes 9 and 10 , as lines $6-8$ but devoid of carrying transgene. The arrow on the left indicates the 19-kb HindIII fragment that is present in the B10.WR7 (transgene donor) genome, in cosmid 38.3, but not in SJL/J and C57B1/6J mice. Lower case letters on the left indicate HindIII fragments in $\mathrm{C} 57 \mathrm{~B} 1 / 6 \mathrm{~J} \times \mathrm{SJL} / \mathrm{J} \mathrm{F}_{1}$ mice that are of endogenous $\mathrm{C} 4$ and Slp origin; fragment a is specific to $\mathrm{SJL} / \mathrm{J}$ chromosomes, fragments $\mathrm{b}$ and $\mathrm{d}$ indicate $\mathrm{C} 57 \mathrm{~B} 1 / 6 \mathrm{~J}$ chromosomes. 
Table 1. Relationship between estimated gene copy number in founder mice and sex-limited protein (Slp) activity in first generation $\mathrm{F}_{1}$ (founder $\times \mathrm{C} 3 \mathrm{H}$ ) mice*

\begin{tabular}{lcc}
\hline Founder & Approx. gene copy & Slp activity \\
\hline A & $15-20$ & +++ \\
B & $10-15$ & ++ \\
C & $15-20$ & +++ \\
$-\dagger$ & 0 & - \\
\hline
\end{tabular}

\begin{abstract}
* Progeny from three independent transgenic lines were tested for Slp activity in a functional complement assay. SlpB gene copy numbers were estimated from relative band intensities on blots similar to those in Fig. 2. Relative Slp activities are indicated by pluses and minuses, based on activity of first generation progeny tested for each founder.

$\dagger$ These mice correspond to lanes 9 and 10 of Fig. 2 .
\end{abstract}

26-kb EcoRI fragment within which resides the 17-kb Slp structural gene and approx. $5 \mathrm{~kb}$ of $5^{\prime}$ flanking and $4 \mathrm{~kb}$ of $3^{\prime}$ DNA sequences [2]. This DNA was microinjected into fertilized mouse oocytes resulting from crossing $\mathrm{C} 57 \mathrm{~B} 1 / 6 \mathrm{~J}\left(\mathrm{H}-2^{\mathrm{b}}\right.$; high $\mathrm{C} 4$ and absent Slp expression) with $\mathrm{C} 57 \mathrm{~B} 1 / 6 \mathrm{~J} \times \mathrm{SJL} / \mathrm{J}\left(\mathrm{H}-2^{\text {s; }}\right.$ high $\mathrm{C} 4$ and low Slp expression) heterozygotes. Progeny was screened by Southern blotting to assess not only the presence of the transgene, but also insertion copy numbers and the haplotype of founders at the endogenous C4 and Slp loci. A 19-kb HindIII fragment unique to the introduced gene clearly revealed the presence of the transgene (Fig. 2). Restriction fragment length polymorphism of other bands hybridizing with the C4/Slp cDNA probe allowed discernment of haplotypes $\mathrm{b}, \mathrm{s}$, and $\mathrm{k}$. Three $(\mathrm{a}-\mathrm{c})$ of the original positive mice, with approximate gene copy numbers ranging from a few to over 20, are represented in Table 1 . These three mice were used to found independent transgenic lines by mating them to $\mathrm{C} 3 \mathrm{H}$ mice $\left(\mathrm{H}-2^{\mathrm{k}}\right.$; C4 low, Slp Q0) and subsequently to C57B1/6J mice.
Slp transgene-negative mice were not included in the breeding programme.

\section{Haemolytic complement assays}

Crossing the Slp transgene into $\mathrm{C} 57 \mathrm{~B} 1 / 6 \mathrm{~J}$ mice and repeated backcrossings yielded the third backcross generation of Slptransgenic mouse lines A, B, and C. These lines were tested for EDTA-resistant, classical $\left(\mathrm{CH}_{50}\right)$, and alternative $\left(\mathrm{AP}_{50}\right)$ complement pathway activities. The results are listed in Table 2 . The lines were subgrouped into Slp-negative $(<200 \mathrm{U} / \mathrm{ml})$ and Slp-positive ( $>200 \mathrm{U} / \mathrm{ml}$ ). For all lines and both sexes, we found two-to-threefold enhanced $\mathrm{CH}_{50}$ levels in the Slp-transgenic mice compared with Slp-negative mice. However, the $\mathrm{AP}_{50}$ levels of sera from Slpnegative and Slp-positive members were not different. To show that $\mathrm{CH}_{50}$ titres correlated with Slp titres, we calculated Pearson's correlation coefficient for the three lines and sexes (Table 3). We found a high correlation in lines $\mathrm{A}$ and $\mathrm{C}$, a weak correlation for the male members of line $\mathrm{B}$, and no correlation at all for the female littermates of line B. Because of the unexpected behaviour of line $\mathrm{B}$, breeding of this line was discontinued.

\section{Protective role of Slp in SLE-prone mice}

In order to study the role of Slp in SLE-prone mice, an introductory study with $\mathrm{NZB} \times \mathrm{W}$ mice was undertaken. The Slp-transgenic $\mathrm{NZB} \times \mathrm{W}$ mice were obtained in the following manner: mice of the first backcross of Slp-transgenic with C57B1/6J mice of line C were crossed with NZB mice $\left(\mathrm{H}-2^{\mathrm{d}}\right.$; high $\mathrm{C} 4$ and sex-limited Slp expression) and backcrossed three times. The thus acquired thirdgeneration Slp-transgenic NZB mice were then crossed with NZW mice $\left(\mathrm{H}-2^{\mathrm{z}}\right.$; high $\mathrm{C} 4$ and absent Slp expression). Twenty-four female $F_{1}$ Slp-transgenic NZB $\times W$ mice and an equal number of non-transgenic littermates (age matched) born from these crossings were used in the pilot study and followed for 1 year. The results are given in Fig. 3. The median survival time of non-transgenic mice was $203 \pm 11.43$ days (mean \pm s.d.), whereas Slp-transgenic animals lived $31 \%$ longer (i.e. $266 \pm 8.57$ days). Statistical analysis

Table 2. Functional sex-limited protein $(\mathrm{Slp}), \mathrm{CH}_{50}$, and $\mathrm{AP}_{50}$ levels in third generation backcross Slp-transgenic and non-transgenic mice $\dagger$

\begin{tabular}{|c|c|c|c|c|c|c|c|}
\hline & & \multicolumn{3}{|c|}{$\begin{array}{l}\text { Transgene-negative } \mathrm{C} 57 \mathrm{Bl} / 6 \mathrm{~J} \text { mice } \\
\qquad(\leq 200 \mathrm{U} / \mathrm{ml})\end{array}$} & \multicolumn{3}{|c|}{$\begin{array}{l}\text { Transgene-positive C57Bl/6J mice } \\
\text { (>200 U/ml) }\end{array}$} \\
\hline & & $\begin{array}{l}\mathrm{Slp} \\
(\mathrm{U} / \mathrm{ml})\end{array}$ & $\begin{array}{l}\mathrm{CH}_{50} \\
(\mathrm{U} / \mathrm{ml})\end{array}$ & $\begin{array}{l}\text { AP50 } \\
(\mathrm{U} / \mathrm{ml})\end{array}$ & $\begin{array}{l}\text { Slp } \\
(\mathrm{U} / \mathrm{ml})\end{array}$ & $\begin{array}{l}\mathrm{CH}_{50} \\
(\mathrm{U} / \mathrm{ml})\end{array}$ & $\begin{array}{l}\mathrm{AP}_{50} \\
(\mathrm{U} / \mathrm{ml})\end{array}$ \\
\hline \multirow[t]{2}{*}{ Line A } & M & $\begin{aligned} 23 & \pm 1 \\
(n & =8)\end{aligned}$ & $\begin{array}{c}317 \pm 31 \\
(n=8)\end{array}$ & $\begin{array}{l}613 \pm 27 \\
(n=8)\end{array}$ & $\begin{array}{l}5125 \pm 934 \\
(n=12)\end{array}$ & $\begin{array}{c}1136 \pm 114 * * * \\
(n=12)\end{array}$ & $\begin{array}{l}655 \pm 25 \\
(n=12)\end{array}$ \\
\hline & $\mathrm{F}$ & $\begin{array}{r}61 \pm 15 \\
(n=7)\end{array}$ & $\begin{array}{c}133 \pm 11 \\
(n=7)\end{array}$ & $\begin{array}{c}243 \pm 12 \\
(n=7)\end{array}$ & $\begin{array}{l}4073 \pm 900 \\
\quad(n=13)\end{array}$ & $\begin{array}{c}212 \pm 22^{* *} \\
(n=13)\end{array}$ & $\begin{array}{r}259 \pm 10 \\
(n=13)\end{array}$ \\
\hline \multirow[t]{2}{*}{ Line B } & M & $\begin{aligned} 152 & \pm 23 \\
(n & =9)\end{aligned}$ & $\begin{array}{c}441 \pm 85 \\
(n=9)\end{array}$ & $\begin{array}{c}332 \pm 39 \\
(n=9)\end{array}$ & $\begin{array}{l}9076 \pm 1801 \\
\quad(n=21)\end{array}$ & $\begin{array}{c}789 \pm 130^{*} \\
(n=21)\end{array}$ & $\begin{array}{l}323 \pm 35 \\
(n=19)\end{array}$ \\
\hline & $\mathrm{F}$ & $\begin{array}{c}72 \pm 12 \\
(n=8)\end{array}$ & $\begin{array}{l}43 \pm 13 \\
(n=8)\end{array}$ & $\begin{array}{c}182 \pm 30 \\
(n=8)\end{array}$ & $\begin{array}{c}5649 \pm 20 \\
(n=18)\end{array}$ & $\begin{array}{l}79 \pm 20 \\
(n=18)\end{array}$ & $\begin{array}{l}165 \pm 10 \\
(n=18)\end{array}$ \\
\hline \multirow[t]{2}{*}{ Line $C$} & M & $\begin{array}{c}6 \pm 4 \\
(n=9)\end{array}$ & $\begin{array}{c}222 \pm 15 \\
(n=9)\end{array}$ & $\begin{array}{c}323 \pm 21 \\
(n=9)\end{array}$ & $\begin{array}{r}760 \pm 9 \\
(n=9)\end{array}$ & $\begin{array}{l}465 \pm 59 * * * \\
\quad(n=9)\end{array}$ & $\begin{array}{c}280 \pm 38 \\
(n=9)\end{array}$ \\
\hline & $\mathrm{F}$ & $\begin{array}{l}2 \pm 1 \\
(n=9)\end{array}$ & $\begin{array}{l}96 \pm 11 \\
(n=9)\end{array}$ & $\begin{array}{r}108 \pm 4 \\
(n=9)\end{array}$ & $\begin{array}{l}4652 \pm 787 \\
\quad(n=6)\end{array}$ & $\begin{array}{c}177 \pm 16^{* * * *} \\
(n=6)\end{array}$ & $\begin{array}{c}116 \pm 11 \\
(n=6)\end{array}$ \\
\hline
\end{tabular}

$\dagger$ Functional Slp activities as well as $\mathrm{CH}_{50}$ and $\mathrm{AP}_{50}$ levels (mean \pm s.e.m.) in male (M) and female (F) Slp-transgenic and non-transgenic mice of three different backcrossings with $\mathrm{C} 57 \mathrm{~B} 1 / 6 \mathrm{~J}$ mice. The mice of different lines were matched for age (animals of the same litters were used). Difference between the mean of Slp-transgene-negative and that of Slp-transgene-positive mice is significant: $* P<0 \cdot 025 ; * * P<0.005 ; * * * P<0.0005$. 
Table 3. Pearson's correlation coefficient between sex-limited protein (Slp) and $\mathrm{CH}_{50}$ titres in three different Slp-transgenic C57B1/6J lines

\begin{tabular}{cccc}
\hline & & $\begin{array}{c}\text { Correlation } \\
\text { coefficient }\end{array}$ & $\begin{array}{c}P \text { value } \\
\text { (two-tailed) }\end{array}$ \\
\hline Line A & M & 0.7503 & $<0.0001$ \\
Line B & F & 0.7614 & $<0.0001$ \\
& M & 0.3917 & $<0.025$ \\
Line C & F & 0.1856 & NS \\
& F & 0.7511 & $<0.0001$ \\
& 0.7466 & $<0.0001$ \\
\hline
\end{tabular}

M, Male; F, female; NS, not significant.

based on Kaplan-Meier survival scoring showed that the life spans of Slp-transgenic and Slp-non-transgenic mice were significantly different $(P=0 \cdot 009)$.

\section{DISCUSSION}

The present studies were performed in order to assign functional activity to mouse Slp. Earlier studies indicated that Slp expresses functional activity in a rather artificial, EDTA-resistant mouse complement activation pathway [5]. Here, we report the generation of Slp-transgenic mice and, after mating these animals to $\mathrm{C} 3 \mathrm{H}$ mice, the crossing and repeated backcrossing of the Slp transgene with $\mathrm{C} 57 \mathrm{Bl} / 6 \mathrm{~J}$ and, after two generations, also with NZB mice.

The transgene elevated $\mathrm{CH}_{50}$ levels in both male and female, third-backcross generation $\mathrm{C} 57 \mathrm{Bl} / 6 \mathrm{~J}$ mice, which strongly suggests that constitutively expressed Slp is a functional component involved in mouse classical complement pathway activation. The significant correlation between functional Slp and $\mathrm{CH}_{50}$ titres in transgenic mouse lines $\mathrm{A}$ and $\mathrm{C}$ corroborates the direct involvement of Slp in mouse complement (Table 2). A less likely, but not entirely impossible, alternative interpretation of our results could be that Slp competes with $\mathrm{C} 4$ for binding sites on complement regulator $\mathrm{C} 4$-binding protein $(\mathrm{C} 4 \mathrm{BP})$, which could render $\mathrm{C} 4$ relatively resistant to regulation by $\mathrm{C} 4 \mathrm{BP}$. However, data from Ferreira et al. [7] do not support C4BP binding to Slp. Very recent

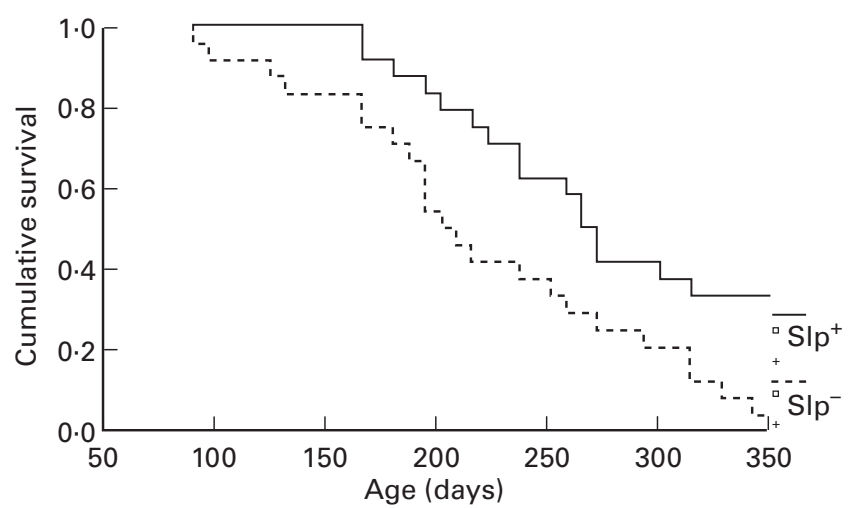

Fig. 3. Sex-limited protein (Slp)-mediated, enhanced survival of female $\mathrm{NZB} \times \mathrm{W}$ mice (line C). Kaplan-Meier survival plots are given which describe the fate of female Slp-positive $(n=24)$ and corresponding Slpnegative $\mathrm{NZB} \times \mathrm{W}$ mice ( $n=24$; from the same litters). Log rank analysis revealed a significant $(P=0.009)$ difference in life span. results from our group, in agreement with literature data [17], indicate that Slp is deposited onto the membranes of sensitized sheep erythrocytes during complement activation. This, in turn, favours a direct, functional role for Slp.

Overall, Slp-transgenic animals showed 60-2400-fold enhanced Slp levels compared with non-transgenic littermates.

Experiments are underway that might reveal the possible mechanism of Slp-mediated complement activation. Preliminary results with regard to $\mathrm{C} 4$ and Slp deposition on sensitized sheep erythrocytes confirm earlier data which show that Slp can bypass C3 and mediates direct activation of C5 [5]. Similar C3-bypass activation pathways have been identified in humans in which $\mathrm{C} 4$ dimers and the activated protease unit of $\mathrm{C} 2 \mathrm{a}$ have the ability to activate C5 without the typically participation of C3 [18].

The extended life span of female, Slp-transgenic NZB $\times W$ mice suggests that Slp has a protective function with regard to disease development in SLE-prone mice. This function is similar to that of C4A in humans, one of the major protective factors in familial SLE $[19,20]$. The protective effect of Slp may be based on the prevention of immune complex precipitation (PIP) or the solubilization (SOL) of already formed immune complexes in vivo. We are now working on an in vitro model system to study PIP and SOL in mice. Preliminary data obtained so far with this system indicate that Slp indeed mediates PIP and SOL in serum of female $\mathrm{NZB} \times \mathrm{W}$ mice.

In conclusion, our data are in favour of a functional role for Slp in mouse classical complement pathway activation and in the prevention of disease development in SLE-prone $\mathrm{NZB} \times \mathrm{W}$ mice. Recently obtained preliminary results suggest that the diseasepreventing effect is mediated by a better handling of immune complexes rather than a regulation of anti-dsDNA autoantibody formation in $\mathrm{NZW} \times \mathrm{B}$ mice. Whatever the exact mechanism might be behind the life-extending effect of Slp in Slp-prone mice, our results are in favour of functional roles for Slp.

\section{ACKNOWLEDGMENTS}

We thank Thom Saunders and Sally Camper of the University of Michigan Transgenic Animal Model Core for the generation of Slp-transgenic mice, and Cathy TomHon for technical assistance. The authors are indebted to Dr P. Démant (Dutch Cancer Institute; NKI, Amsterdam, The Netherlands) for his suggestion to generate Slp-transgenic mice. This work was supported in part by grants from NIH (D.M.R.).

\section{REFERENCES}

1 Hogan B, Constantini F, Lacy E. Manipulating the mouse embryo: a laboratory manual. Cold Spring Harbor, NY: Cold Spring Harbor Laboratory, 1986.

2 Stavenhagen JB, Loreni F, Hemenway C, Kalff M, Robins DM. Molecular genetics of androgen-dependent and -independent expression of mouse sex-limited protein. Mol Cell Biol 1987; 7:1716-24.

3 Miller SA, Dykes DD, Polesky HF. A simple salting out procedure for extracting DNA from human nucleated cells. Nucleic Acids Res 1988; 16:1215.

4 Hemenway C, Kalff M, Walthall D, Robins D. Sequence comparison of alleles of the fourth component of complement (C4) and sex-limited protein (Slp). Nucleic Acids Res 1986; 14:2539-54.

5 Van den Berg CW, Demant P, Aerts PC, Van Dijk H. Slp is an essential component of an EDTA-resistant activation pathway of mouse complement. Proc Natl Acad Sci USA 1992; 89:10711-5.

6 Robins DM, Malissen M, Hood L, Ferreira A, Walthall D, Mitchell M. Multiple C4/Slp genes distinguished by expression after transfection. Mol Cell Biol 1986; 6:134-41. 
7 Ferreira A, Nussenzweig V, Gigli I. Structural and functional differences between the H-2 controlled Ss and Slp proteins. J Exp Med 1978; 148:1186-97.

8 Nonaka M, Nakayama K, Yeul YD, Takahashi M. Complete nucleotide and derived amino acid sequences of sex-limited protein (Slp), nonfunctional isotype of the fourth component of mouse complement (C4). J Immunol 1986; 136:2989-93.

9 Ogata R, Low PJ, Bradt BM, Cooper NR. Substrate specificities of murine C1s. J Immunol 1994; 152:5890-5.

10 Ogata RT, Low PJ, Kawakami M. Substrate specificities of the protease of mouse serum ra-reactive factor. J Immunol 1995; 154:2351-7.

11 Chaplin DD, Woods DE, Whitehead AS, Goldberger G, Colten HR, Seidman JG. Molecular map of the murine S region. Proc Natl Acad Sci USA 1983; 80:6947-51.

12 Shreffler DC. MHC-linked complement components. In: Parham P, Strominger J, eds. Histocompatibility antigens: structure and function (receptors and recognotion, Series B, Vol. 14). London: Chapman \& Hall, 1982:187-219.

13 Rosa PA, Sepich DS, Robins DM, Ogata RT. Constitutive expression of Slp genes in mouse strain B10.WR directed by $\mathrm{C} 4$ regulatory sequences. J Immunol 1987; 139:1568-77.

14 Nakayama K, Nonaka M, Yokoyama S, Yeul DY, Pattanakitsakul SN, Takahashi M. Recombination of two homologous MHC class III genes of the mouse (C4 and Slp) that accounts for the loss of testosteronedependence of sex-limited protein expression. J Immunol 1987; 138:620-7.

15 Klerx JP, Beukelman CJ, Van Dijk H, Willers JM. Microassay for colorimetric estimation of complement activity in guinea pig, human and mouse serum. J Immunol Methods 1983; 63:215-20.

16 Van Dijk H, Rademaker PM, Willers JMN. Estimation of classical pathway of complement activity by use of sensitized rabbit erythrocytes. J Immunol Methods 1980; 39:257-68.

17 Ogata RT, Cooper NR, Bradt BM, Mathias P, Picchi MA. Murine complement component $\mathrm{C} 4$ and sex-limited protein: identification of amino acid residues essential for $\mathrm{C} 4$ function. Proc Natl Acad Sci USA 1989; 86:5575-9.

18 Masaki T, Matsumoto M, Hara T, Nakanishi I, Kitamura H, Seya T. Covalently bound human $\mathrm{C} 4 \mathrm{~b}$ dimers consisting of C4B isotype show higher hemolytic activity than those of C4A in the C3-bypass complement pathway. Mol Immunol 1995; 32:21-6.

19 Hauptmann G, Tappeiner G, Schifferli JA. Inherited deficiency of the fourth component of the human complement. Immunodefic Rev 1988; 1:3-22.

20 Beurskens FJM, Van Dijk H, Robins DM. Does complement component C4A protect from autoimmune disease? Immunol Today 1997; 18: 199 . 